\title{
Eating their words: food and text in the coronation banquet of Henry VI
}

Robert Epstein Dr.

repstein@fairfield.edu

Follow this and additional works at: https://digitalcommons.fairfield.edu/english-facultypubs

Copyright 2006 Duke University Press

The author post-print has been archived here with permission from the copyright holder.

\section{Peer Reviewed}

\section{Repository Citation}

Epstein, Robert Dr., "Eating their words: food and text in the coronation banquet of Henry VI" (2006).

English Faculty Publications. 123.

https://digitalcommons.fairfield.edu/english-facultypubs/123

\section{Published Citation}

Epstein, Robert. "Eating their words: food and text in the coronation banquet of Henry VI." Journal of Medieval and Early Modern Studies 36, no. 2 (2006): 355-377. https://doi.org/10.1215/10829636-2005-005.

This item has been accepted for inclusion in DigitalCommons@Fairfield by an authorized administrator of DigitalCommons@Fairfield. It is brought to you by DigitalCommons@Fairfield with permission from the rightsholder(s) and is protected by copyright and/or related rights. You are free to use this item in any way that is permitted by the copyright and related rights legislation that applies to your use. For other uses, you need to obtain permission from the rights-holder(s) directly, unless additional rights are indicated by a Creative Commons license in the record and/or on the work itself. For more information, please contact digitalcommons@fairfield.edu. 
Eating Their Words:

Food and Text in the Coronation Banquet of Henry VI

\author{
A Master-Cooke! Why, he is the man of men, \\ For a Professor! He designes, he drawes, \\ He paints, he carues, he builds, he fortifies, \\ Makes Citadels of curious foule, and fish, \\ Some he dry-ditches, some motes round with broths; \\ Mounts marrow-bones; cuts fifty-angled custards; \\ Reares bulwarke pies; and, for his outer workes, \\ He raiseth ramparts of immortall crust; \\ And teacheth all the tacticks at one dinner: \\ What rankes, what files, to put his dishes in; \\ The whole Art Militarie! \\ -Ben Jonson, Neptune's Triumph for the Return of \\ Albion ${ }^{\mathrm{i}}$ \\ I do not wish to cast doubt that, in spite of \\ everything, there were found among all the \\ displays of the festival, particularly among the \\ sculptural pieces, a good many genuine works of \\ art alongside the predominantly silly ostentation.
}


We should remember that the people who delighted in this gargantuan splendor and wasted serious thought on it were the same people who commissioned the works of Jan van Eyck and Rogier van der Weyden... Even at the risk of sacrilege, it is tempting to go one step further and assert that on occasion we have to keep in mind the lost art of table decoration, now completely vanished, in order to better understand Claus sluter and others like him. -Johan Huizinga, The Autumn of the Middle $\underline{\text { Ages }}^{\text {ii }}$

In the medieval and early-modern feast, Ben Jonson realized, cuisine was the continuation of politics by other means. The banquet table could express and advance the ideology and aspirations of the host. At the same time, as Huizinga observes, table decoration was art, as symbolically complex and significant as the paintings and sculptures of the Old Masters. This art is not, however, "completely vanished." To see a feast that is self-consciously and patently public, in which the food is extravagant and exotic and elaborately symbolic, that addresses clear and immediate political concerns, and that marshals archaic and arcane 
rituals to demonstrate the power and resources of the host, we need look no further than to a White House state dinner. President George W. Bush's first state dinner, on September 5, 2001, honored President Vicente Fox of Mexico. Free trade in North America was central to the political visions of both presidents, and courting Hispanic-American voters was one of Bush's primary goals for the Republican Party. Bush's first state dinner was meant to showcase that relations with Latin America constituted his administration's foremost foreign policy priority. (In less than a week, history would violently intervene to make this ambition obsolete.) The dinner therefore celebrated Mexican-American cultural, economic, and geographic integration, and this agenda was manifested in the food. The menu was self-consciously haute Tex-Mex: an appetizer of Maryland crab and chorizo pozole; a main course of pepitacrusted crusted bison with poblano whipped potatoes, fava bean and chantarelle ragout, and apple chipolte sauce; a salad of gold and red tomatoes; for dessert, a mango and coconut ice cream dome with peaches and red chile pepper sauce. iii The guests at this dinner must have been aware at some level that the gold and red tomatoes in their salads echoed the colors of the Mexican flag and that the crab in the appetizer, from the waters near Washington, was mixed with Mexican chorizo. In the main course they were 
essentially eating icons of the North American landscape, traditional symbols of the U.S.-- bison, apples-- that here were graciously infused with Mexican flavors. The centerpieces, meanwhile, featured limes, a major Mexican export. iv The most elaborate symbolism appeared in the dessert, the work of the White House pastry chef, an uncommonly creative Master-Cooke named Roland Mesnier. The ice cream dome on each table was planted with miniature Mexican and U.S. flags as well as a branch with hibiscus flowers and hummingbirds-- all made out of spun sugar. ${ }^{\text {v }}$ The guest list at the banquet followed custom in including powerful politicians, wealthy campaign contributors, and stars of sports and entertainment, many of them with ethnic connections to the guest nation. ${ }^{\text {i }}$ These guests are the consumers of the meal, but they are also part of the spectacle; they are simultaneously spectators and performers.

Each of the elements in this modern political feast-the occasion encoding diplomatic and political symbolism; the symbolically significant food; the incorporation of symbols into the meal-- has its medieval analog. Of particular interest, though, is the final element of the performance, the entry of the event into the historical record. The menu for the Fox dinner was printed in its entirety in newspapers across the country, while some, 
notably the Washington Post (in its role as the program of power in the capital), published a complete list of the attendees. The modern reporting on the sumptuousness of political celebrations resembles nothing so much as medieval chronicle entries on royal festivities, including the minute recording of the attendees, their titles, their order of entry and their seating arrangements. In both the medieval and the modern instances, the recording of the events in authoritative sources extends the political performance into the textual realm, where they can survive for much longer and influence a much larger audience.

This textual preservation is especially significant in light of one of the seemingly essential qualities of the political spectacle, its ephemerality. Much as we-- we who are not invited-- like to think that extravagant occasions like White House state dinners are just so much profligate frivolity (though we are glad to read about them or watch snippets on television), medieval aristocratic entertainments like banquets have until recently received little attention and less respect. As Stephen Orgel says of a similar genre of spectacle, the stuart masque, "It is probably the ephemeral quality of the form that really disturbs us most, conditioned by a strongly moral sense of artistic economy-all that money for only two performances!"vii While Huizinga's core assertion is that 
the spectacular feasts and entertainments of the FrancoBurgundian courts were potentially as valuable and meaningful as the recognized treasures of the Flemish masters, still he maintains that the greatest distinction between them is that the art survives, whereas the spectacles were transitory: "The separation of all that bizarre decoration, which has vanished without a trace, from the individual works of art that have been preserved, a separation that our appreciation of art demands and that has been aided by the all destroying passage of time, hardly existed for contemporaries" (311). To Huizinga, the creators and viewers of these spectacles appreciated them precisely for the transient pleasures of their ostentation, and they made no efforts to preserve them. The festivities, for all their "wasteful splendor" and "splendidly bloated vanity" (294), left no monuments.

It is a sad fact that very few concrete artifacts survive of the spectacular festivities and public performances that saturated fifteenth-century culture. This does not necessarily prove, however, that these special performances were thought of as purely ephemeral and that no thought was given to preserving them. In at least one sense, many did indeed leave monuments. They left texts. The documentary remnants of medieval spectacles have been invaluable resources for historians of theater and 
performance. ${ }^{\text {vii }}$ Recent histories of performance have begun to apply models of textual criticism to public spectacles, seeking not merely to reconstruct the events but to interpret them as if they were texts themselves. Lawrence M. Bryant, for instance, acknowledges "the role of the analysis of textuality in reconstructing historical events" and adds, "We cannot disassociate the performances from the 'historical event' of which they are a component part; spectacles cannot be taken as transparent and unproblematic descriptions of historical events." "ix The text itself, meanwhile, remains in such analyses essentially a source to reveal the true object of study, the performance. Rather than mere documentary evidence, though, such texts are also the legacies of the spectacular events they describe, their surviving monuments, and they should be interpreted as artifacts in their own rights.

Any effort to do so, however, is complicated by the uncertain and varied natures of the texts associated with public spectacles and performances. Some are "performance texts" in the conventional sense of a script or prompt for a performance. Others seem to have accompanied the performance in a different and more separate capacity, and some others were composed after the fact to commemorate a performance or spectacle. Some seem to be combinations of all of these things. Many such texts have traditionally 
been categorized, largely by default, as "occasional" pieces. But it has been observed that occasional poems are occasional only once. Then what are they? What connection survives between the text and the occasion of its composition?

In England in the fifteenth century there began to appear spectacular public "occasions" that approached (without quite achieving) the extravagance and complexity of the Continental tradition of Huizinga's study. ${ }^{x}$ Elaborate and ostentatious spectacles-- triumphal processions, weddings, gift-giving ceremonies, banquets, interludes, mummings, and other courtly entertainments-- were employed to propound the ideology of the Lancastrian dynasty. In fact, the aristocratic performance became most elaborate when the dynastic stability seemed most tenuous, after the premature death of Henry $V$ in $1422 .{ }^{x i}$ Dynastic ideology asserted the magnificence of the Lancastrian kings, even when the king, in the case of Henry VI, was an infant. It asserted, in an atmosphere of increasing factionalism and instability, the unanimous aristocratic support for the dynasty, and the domestic harmony of royal, clerical, and common interests. It asserted the unerring commitment of the Crown to the protection of Church privileges, when the partnership had been cemented only relatively recently, and the inviolability of Ecclesiastical prerogatives, in the 
face of intractable Wyclifite heresy. And it asserted, despite any rationality allowable in international politics, the ideological coherence and the political viability of the dual monarchy of England and France.

A significant number of poetic texts survive from these Lancastrian occasions, most of them by John Lydgate. Lydgate devoted much of his long life to composing verses for the patronage of Henry $V$ and Humphrey of Gloucester, but it was an intense period of composition for Henry VI in the late $1420 \mathrm{~s}$ and early $1430 \mathrm{~s}$ that earned him the reputation of the dynasty's unofficial laureate and chief propagandist. The exact relationship between the Lancastrian spectacles and Lydgate's texts, however, remains far from clear. There is considerable formal variety among the texts, but all of them crystallize essential issues of power, poetry, and dynastic representation, while also raising complicated questions for the relationship of the written text to the public performance.

In the summer of 1429, the Dauphin Charles was crowned King of France at Rheims. At that time, Henry VI was still only eight years old, and his official coronation should have been years away, but Charles's coronation required a response. Preparations began for Henry's French coronation, which would eventually take place in Paris in 1431. But first, Henry would have to be crowned king of England. The 
English coronation was performed on November 6, 1429. ${ }^{\text {iii }}$ Naturally, the celebrations of the event included a banquet. This was the occasion for Lydgate's "The Soteltes at the Coronation Banquet of Henry VI," which preserves, in provocative conjunction, a documentary record of the spectacular occasion and the poetic text that both participated in it and survives after it. With some variation among manuscripts, the text of the "Coronation Banquet" lists the menus of each of the three courses at the banquet, with brief descriptions of the "soteltes," or illustrative tableaux, presented with each course, and the eight-line verse stanzas by Lydgate that accompanied each "sotelte."xiv

While performance is by nature ephemeral, food is actually perishable. But those transient qualities that made eating of lesser significance to earlier scholarship are precisely what make it fascinating to performance artists and performance studies. ${ }^{x v}$ What the text of the "Coronation Banquet" first drives home is the central role of the food in this aristocratic performance:

This was the first cours at his coronacion, that is to say, first, ffurmentie, with venyson. Viande Royal plantid with losenges of golde. Borehedes in castelles of earmed with golde. Beef. Moton. Signet. Capon stued. Heron. Grete pike. A redde lech with lions 
corven theryn of white. Custade Rooial with a leparde of golde sittyng theryn. Fritour like a sonne with a flour de lice therynne.

Some of the dishes described here attest to the very different conventions of medieval cuisine. "Furmenty with venison" and "viande royal," for instance, were both popular, porridge-like dishes; they were sweet, they were served with meat, and they came in this case at the beginning of the meal. ${ }^{x v i}$ In reading this menu, though, one must be struck primarily by the number and variety of types of flesh, fish, and fowl. The diners were served venison, boarshead, beef, mutton, signet, capon, heron, and pike, in addition to the chopped meats and sliced sausages in the fritters and custards - and this was just the first course. Still to come were the pork, crane, rabbit, chicken, partridge, peacock, egret, cock, plover, quail, snipe, lark, carp, crab, and much more. Naturally, one expects luxury at a coronation, but this menu evokes not just a cornucopia but an ark. In the reading, the variety and the quantity of items, the care taken to record each delicacy, give an impression of magnificent superfluity. Clearly, the food at the banquet, in its abundance and extravagance, forms a part of the royal performance, and its purposes are in large part political. Like the spectacle that surrounds it, the banquet advertises, at a crucial moment for the dynasty, the 
splendor of the monarch and by extension also the resources and power of the monarchy. A king's liberality in public display, the royal virtue known as "magnificence," is an exhibition of the depth of his resources and therefore of the sufficiency of his wealth and power. This is precisely the kind of demonstration of power the Lancastrian dynasty was eager to produce, as the crown was formally passed to a boy one month short of his ninth birthday.

It is not just our historical distance that makes this feast seem extravagant, exotic, and enormous; any contemporary spectator or participant would have felt the same. xvii Any reader of the text, furthermore, modern or medieval, would get the same impression. The recording of the meal's courses and their publication in authoritative chronicles are the textual afterlife of the banquet, a discursive extension of the culinary performance, like the practice of publishing in major newspapers the menus of White House state dinners. The menus in the "Coronation Banquet" text, therefore, preserve and propagate the performative qualities of the perishable banquet and the ephemeral occasion, recording the event's integration of food, spectacle, and text.

This integration works both ways. What is striking about the chronicle entries for the Henry VI's coronation banquet is not just that there is food in the text, but that 
there is text in the food. The menu items are symbols in the banquet performance, but they also bear signs. While the practice of decorating dishes with colors and symbols was widespread in the Middle Ages, historians of medieval feasting have been impressed by the elaborateness of this banquet, which, P.W. Hammond observes, "seems to have had particularly heraldic food."xviii Throughout the coronation banquet, dishes bear or represent heraldic emblems and patterns, showing that the ostentation of the feast extended to the food's presentation, and furthermore that the food was thoroughly integrated into the symbolism of the spectacular occasion. In the first course, the "viande royal" was "plantid with lozenges of golde" (sliced into geometrical sections which were dyed with saffron), the "redde lech" was inscribed with white lions, the "custade rooial" bore a golden leopard, and the fritter was in the shape of a sun with a fleur-de-lis in the middle. ${ }^{\text {ix }}$ The menu for the first course ends with "A sotelte, seint Edward and Seint Lowes armed in cote armours bryngyng yn bitwene hem the Kyng in his cote armour." King Edward the Confessor of England and King Louis IX of France were both celebrated rulers, both venerated as saints by their respective nations, and most importantly both claimed as ancestors by the Lancastrian monarchs, in the inventive genealogy justifying their dual monarchy. ${ }^{x}$ The lions and leopards in 
the leches and bakemetes of the course would also have appeared in the coats of arms of Edward and Louis, and of Henry VI presented between them. Lydgate's stanza for the tableau (the sotelte appeared, according to the text, "with this scripture suyng") calls attention to the fleur-de-lis, the symbol of Henry VI's bi-national inheritance, which is displayed in the "fritour like a sonne" that is the course's final dish:

Loo here twoo kynges righte perfit and right good, Holy Seint Edwarde and Seint Lowes:

And see the braunch borne of here blessid blode; Live, among Cristen moost souereigne of price, Enheretour of the floure de lice! God graunte he may thurgh help of Crist Ihesu This sext Henry to reigne and be as wise And hem resemble in knyghthod \& vertue.

The third course is equally heraldic, beginning with "Blaunde Surrey poudrid with quatrefoilis gilt" and offering a "lech of iij colours" and "a colde bakemete like a shelde quarterly redde and white, set with lozenges \& gilt, and floures of borage."xxi It was accompanied by a sotelte of the Madonna and Child with the child king:

Our Lady sittyng and hir childe in her lappe, and she holdyng in hir hand a crowne and seint George knelyng 
on that oo side and Seint Denyse on that other side, presentyng the Kyng, knelyng, to Our Lady, with this reason folowyng;

O blessid Lady, Cristes moder deere, And thou seint George, bat callid art hir knight; Holy Seint Denyse, O martir moost entier, The sixt Henry here present in your sight, Shewith of grace on hym your hevenly light, His tendre yougth with vertue doth avaunce, Bore by discent and by title of right Iustly to reigne in England and in Fraunce.

Henry is presented to the Virgin by Saint George, since the fourteenth century the patron saint of England, and saint Denis, long the unofficial patron saint of France. ${ }^{x i i}$ The verses invoke the sainted knight and martyr to call on the Virgin to shed her grace on the young king as he grows into his just rule of both England and France. The emblems and symbols in the food and in the subtlety would have been familiar to the diners from similar Lancastrian propaganda in other media. ${ }^{\text {xiii }}$

The discursive nature of the banquet is most apparent in its second course. Here again the dishes emblazon heraldic symbols, some of them exceptionally elaborate: 
"Viande blank, barrid of golde... Pigge endored... Chikyns endored... Leches white with an antelop of redde corven theryn, a crowne about his neck with a cheyne of golde. Flampayne poudred with lepardis and floure de lices of golde. Fritour, a lepardis hedde with ij ostrich fethers."xxiv In addition to the conspicuous commingling of English leopards and French lilies, there is actual writing in the food: "Gely partid writen and notid Te Deum Laudamus." The words as well as the symbols are appropriate to the accompanying subtlety, which like the others highlights two key figures, in this case the Emperor Sigismund and King Henry V, with Henry VI kneeling before them. They are armed and bear "here mantelles of the garters," which would have duplicated the emblems in the food, and Lydgate's stanza praises them for their martial Christianity and defense of Holy Church: Against miscreauntes themperour Sigismound Hath shewid his myght which is imperial; Sithen Henry the Vth so noble a knyght was founde For cristes cause in actis martial; Cherisshyng the Chirch Lollardes had a falle, To give exaumple to kynges that succede And to his braunche in especiall While he dothe regne to love God \& drede. 
If this feasting on signs and symbols of dynastic polity has some feeling to it of a political mass, it is, I believe, more than incidental. The hallmark of Lancastrian culture, in addition to the overt politicization of poetry and other forms of representation, is the unification of Church and Crown in a marriage of mutual self-interest and self-preservation. ${ }^{x v}$ The Church received the support of the monarchy in the suppression of the Lollard heretics, and protection from all those who would attack its sacraments or its privileges. The Lancastrians got to associate themselves with orthodoxy, and by extension to cast its ever-present enemies as heretics. If the Lollard heresy was, as the title of Ann Hudson's study fashions it, a "premature Reformation," then Lancastrian polity was a premature Counter-Reformation. xxvi $^{\text {ni }}$

Lancastrian culture is shot through with examples large and small of Christian symbols and ecclesiastical customs turned to political purposes, and a number of these appear in the texts and spectacles of Henry VI's coronation. Lydgate's "A Prayer for King, Queen, and People," written in anticipation of the coronation, is a translation of the hymn "Ab inimicis nostris defende nos christe," to which Lydgate appends an envoy asking for God's blessing for the young king and his mother and carefully restating the English claim to France. ${ }^{x x i i}$ In Henry's triumphal entry into London 
after his French coronation the royal procession paused in Cheapside before, as Lydgate describes it in his verses on the occasion, "a castell bilt of iaspar grene" (394), which displayed a pair of parallel genealogies. On one side was the frequently depicted descent of Henry VI from two royal stocks: "Twoo green treen ther grewe vp-ariht/ Fro Seint Edward and ffro seint Lowys, / The roote y-take palpable to the siht, / Conveyed by lynes be kyngis off grete prys; / Some bare leopardes, and some bare fflouredelys..." (398402). xxviii All of these motifs would have been familiar from other sources, including the coronation banquet, ${ }^{x i x}$ but here they were mirrored on the other side of the jasper castle by "a tree, which sprange out off Iesse," (413) the conventional depiction of the genealogy of Christ through David as described in the Gospel of Matthew. ${ }^{x x}$ In the Coronation Banquet itself, the third sotolte shows Henry VI kneeling before the Virgin, who holds the Christ child in her lap and a crown in one hand. That crown is rather ambiguously poised: is she crowning the King of Heaven or the King of England and France? The tableau centers on a religio-political pairing of infants. ${ }^{x x i}$ Such audacious conflations of political and theological imagery demonstrate, as McKenna says, "the lengths to which the English royal administrators were prepared to go to advertise the dynastic claims of Henry VI" (161) . 
Meanwhile, the suppression of heresy loomed alongside the legitimacy of dynastic succession and the dual monarchy as one the three overriding preoccupations of Lancastrian polity. Literature associated with the dynasty, therefore, invariably stressed the orthodoxy of the Lancastrian kings and their persecution of Lollardy. This is particularly clear in Thomas Hoccleve's work for Henry V, such as the "Remonstrance Against Oldcastle" and the Regement of Princes. In a particularly memorable scene in the Prologue to the Regement, Henry V, then the Prince of Wales, himself carries the Eucharist to the Lollard John Badby as he is tied to the stake in smithfield and pleads with the apostate to accept the sacrament.

The Lancastrian cultural project, however, was more comprehensive than these individual examples of royal orthodoxy and symbolic manipulation. The strategic alliance of Church and Crown against Lollardy, the "Lancastrian compromise" if you will, resulted in the dynastic appropriation of ritualistic practices associated with theological orthodoxy and the incorporation of these practices into vernacular literature. The Lollards tended towards iconoclasm. In Ms. Harley 4866, when Geoffrey Chaucer appears in the Prologue to Thomas Hoccleve's Regement of Princes, he is painted onto the page of in an architectural nook that makes him appear like a statue of a 
saint and that seems to venerate him like an icon;

Hoccleve's accompanying defense of religious images fixes the Chaucer portrait in the context of anti-Lollard iconodulism. xxxii The Lollards strove for lay access to scripture in the vernacular, and were suspicious of the Latin eloquence of clerks. Lydgate's famously ornate "aureate" style seems to have been fashioned partly in response, intentionally affecting an extremely Latinate rhetorical eloquence for vernacular, political verse. ${ }^{x x i i i}$ In all these cases, vernacular literary culture is made to mirror the strategic alliance of the Church and the dynasty: ecclesiastical rituals and customs are endowed with royal authority, and dynastic politics take on the trappings of contested religious ritual.

The same process can be seen at work in the "Coronation Banquet." The Lollards had objections to many sacraments, including confession, but their most common and most deeply felt objection was to the doctrine of transubstantiation and the sacrament of the Eucharist. The Eucharist was therefore the most controversial theological issue of the fifteenth century, going to heart of the conflict between orthodoxy and heresy. In the coronation banquet, the food is given the form of dynastic emblems, and consumed by the guests in commemoration of the continuance of the dynastic line. Thus Lancastrian political symbolism once again imports 
embattled, orthodox religious practices into the performance of secular political ritual.

This is most tangible in the second course. The subtlety and the stanza figure and lionize the king's father and the Holy Roman Emperor Sigismund, with whom he had been allied. The evocation of Sigismund, Griffiths asserts, had the purpose of "assuring the popular mind that the dual monarchy had imperial approval - even if the practical value of this sanction was negligible" (220). Henry V had been a savvy player in international politics, and had played Sigismund quite deftly, but Lydgate's verses make clear that Sigismund appears in the banquet primarily not as authorizing emperor but as a persecutor of heretics. It was Sigismund who betrayed Jan Hus at the Council of Constance, authorized his execution, and subsequently warred against his followers. ${ }^{x x i v}$ The coronation banquet links the Hussites and the English Wyclifites in their apostasy, and Sigismund and Henry $V$ in their militant orthodoxy. As Sigismund wielded imperial power "ageinst miscreauntes," Lydgate says, so was Henry V a noble knight for Christ, who defended Holy Church against the Lollards and set an example for succeeding kings, particularly those of his own line. Even as the subtlety displays the effigies of the emperor and the king, even as the verses, inscribed in the subtlety and no doubt read aloud by a herald, praise the two figures for 
their persecution of essentially anti-sacramental heresies, the banquet guests are eating a jellied dish inscribed with the words "Te Deum Laudamus." The significance of the words is threefold: they literally proclaim the diners' devotion to God; being Latin, they take on in context an orthodox connotation; they are a royal motto. In consuming them, the diners use their own bodies to enact and to corporeally signify their fealty to the ideology of Church-Crown cooperation.

In theory, medieval imagination delineates between meal and mass. "The central mystery of the mass," Stephen Nichols observes, "distinguished between the eating as a spiritual activity, a literal in-corporation of transcendent essence, and eating as a physical activity, in short, eating as a commemoration of the human kinship with divinity, and eating as a reminder of the link between the human and the animal body."xxx Henry VI's coronation banquet, both a ritual meal and a secular mass, blurs the distinction. ${ }^{x x v i}$ By importing the disputed practices of ecclesiastical orthodoxy into a festival of secular coronation, the banquet becomes a spectacle of political and theological devotion, in which the guests are simultaneously audience and performers. It is a performance of secularized, politicized communion. 
The banqueters' consumption of signs may not have been limited to the Latin mottoes and heraldic emblems in the dishes; they may have eaten the subtleties themselves. We cannot be sure, unfortunately, exactly what the subtleties were made of. The text of the coronation banquet describes their symbolic meaning but not their medium or their mode of construction. Subtleties originated as palate-cleansing foods offered between courses, but they were made objects of culinary play and became increasingly elaborate over time until they were eventually no longer intended to be eaten.xxvii Unlike their Continental equivalents the entremets, which were sometimes carried in on a bier, subtleties were made to be set on the table. xxxviii Wickham describes subtleties as "tableaux morts... which only require live actors to transform them into the tableaux vivants with which we are familiar in the Tournament and the Pageants of the streets,"xxxix and they would eventually evolve into the dramatic interludes of the Burgundian court so celebrated for their ostentation. ${ }^{x}$ It is not certain where on this continuum Henry VI's coronation banquet lies, but subtleties generically were most often food items, and most authorities characterize Henry's as constructed of some sort of comestible: sugar, marzipan, or dough. xli

Such constructions were novelties, of course, and that they were edible does not necessarily mean that they were 
eaten, but they may have been. (We do not know if President Bush's guests ate their hummingbirds, though they definitely could have.) The guests at the Coronation Banquet, then, may have consumed in their entirety elaborate scenes of Lancastrian pageantry. In fact, they may have ingested Lydgate's verses themselves. It seems likely that the verses were read aloud, but the text of the "Coronation Banquet" emphasizes the visual presence of the verses in the feast. Henry VI appears between sts. Edward and Louis "in his cote armour with this scripture suyng;" he kneels before his father and Sigismund "with this resoun;" he is presented to the Virgin "with this reason folowyng." If, as it seems, the lines were inscribed into the subtleties, then along with the pikes and plovers and peacocks, the saffron leopards and fleurs-de-lis, the gilded chickens, the Latin mottoes in jelly, the effigies of saints with their attributes and kings (including Henry VI, three times) with their coats of arms, the guests may have eaten Lydgate's poetry. xlii The entire banquet - food, image, and text - is a complex, carefully orchestrated performance, completed only with the guests' corporeal ingestion of the signs. Even if the verses were not inscribed into edible subtleties and consumed by the diners, they were nonetheless a visible part of the banquet, fully integrated into a spectacular, participatory, political performance. Just as 
the feasters encountered the verses as part of the meal, furthermore, the reader of "The sotoltes at the Coronation Banquet of Henry VI" encounters the poetry as part of the menu. It is the presence of the poetry in the menu that makes the "Coronation Banquet" such a unique text. Numerous banquet menus survive in manuscript; seven are recorded in Harley 279, including that of the coronation banquet of Henry IV, and in most of them each course ends with "a sotelte."xliii In other places subtleties are described in greater detail. The "Great Chronicle" also records the banquet for the coronation of Henry VI's mother Katherine in London in 1420. The chroniclers made particular efforts to note the subtleties, which are conspicuously elaborate and discursive:

A sotilte called pellycan on his nest with briddes and an Image of seint kateryn with a boke in hyre hande dysputing with the hethen clerkes havyng this Reson in hyre hande Madame la Reigne The pellican answering Ceste enseigne The briddes answering est duroy pur tenir Joy A tout gent il mette sentent. xliv What makes the text of Henry VI's "Coronation Banquet" special is the preservation of Lydgate's verses in the context of the menus and the detailed descriptions of the subtleties. It is in this context, a text of a feast in which the food is conspicuously discursive, that we should 
understand the function of Lydgate's poem and the overall textual legacy of the banquet. This is why the journalism of state dinners seems to me especially pertinent to this branch of the medieval textual record: it speaks to the nature of the "occasional" text and its relationship to its occasion. If "The Soteltes at the Coronation Banquet of Henry VI" is a script for performance, why is it preserved, and why does it include the food? If it is a commemoration of an important public event, why not describe event, set it in context, relate the scene? And why not versify the victuals? Why include them in the text but leave them in prose, separate from the verses and, as it were, undigested? I think that pun may actually indicate the answer: the reader encounters, like the attendees to the banquet, the verse and the food together, and must assimilate both. The text in a sense recreates the occasion. When the text of the jellied dish is written into a menu, which is written into a manuscript, along with the written description of the spectacle, and the written inscriptions of Lydgate's verses, the entire text comes to replicate the conditions of the original public performance. The readers of this manuscript would metaphorically consume words in a manner analogous to the literal consumption of words at the original banquet. In a sense, the final act in the performance of the banquet is the consumption of the stage and props and the script 
itself by performers who are also the audience; in a broader sense, the performance extends to the textual afterlife of the event, wherein the reader is like an audience member, witnessing the spectacle, and like a performer, actively completing the show.

Many predominantly prose chronicles incorporate passages of verse. Julia Boffey and A. S. G. Edwards have shown that such passages tend to be scattered and to appear without any clearly discernible pattern or program. They ascribe most such appearances of verse to "random access to illustrative material."xlv Boffey and Edwards point to the inclusion of Lydgate"s "Soteltes" in chronicles as an example of this kind of "opportunistic interpolation."xlvi For instance, the text is one of only three interpolations of verse into Gregory's Chronicle (BL Egerton 1995). xlvii I would suggest, though, that given the text's inclusion in nine chronicle manuscripts, including some like Gregory's that have few other verse interpolations, its appearance may be more "opportunistic" than "random." That is, while the verses would seem to be the epitome of the "occasional" text, composed to explicate a political-allegorical performance, they may have been circulated so that they could be included in other, more widespread, more permanent texts like chronicles. xlviii 
In fact, the banquet and the text of the banquet may metaphorically represent authorized models of textual production and reception. Like other Lancastrian texts, they explicitly promulgate dynastic ideology and implicitly appropriate contested orthodox ritual. The very act of reading in Lancastrian culture evokes rituals, performances, and displays with endless public and political ramifications. Textual reception in Lancastrian culture, the reading of the texts assiduously produced and disseminated by the anxious dynasty, can itself be seen as an act of political communion, in which the ideology of the regime is symbolically consumed and internalized.

The "Coronation Banquet" thus clearly reveals Lydgate in his role as Lancastrian propagandist, but this was not his only role. Elsewhere Lydgate is depicted as contentprovider to proto-bourgeois book-buyers. In a study of Lydgate's "Dietary," another food-based text, claire Sponsler situates the consumption of food in the context of incipient consumer culture. ${ }^{\text {xlix }}$ sponsler argues that the "Dietary," like other fifteenth-century conduct manuals, is aimed at bourgeois or prosperous non-aristocratic propertyowners, a class conscious of its distinction from betters as well as inferiors, to whom Lydgate's text offers advice on turning food into symbolic capital: 
The prosperous householder of Lydgate's poem is not encouraged to follow food consumption patterns associated with elites, but instead is offered a new way of eating, one which allows him to escape direct competition with aristocratic privilege by retreating into the enclosed space of private consumption whose value rests less on public approbation than on individual health and happiness... Lydgate's "Dietary" would function as a privatized educational system designed to produce competent consumers able properly to value symbolic goods - in this case, food - and hence to maintain cultural distinctions at a time when food items once confined to the aristocracy are becoming more widely available and therefore weakening earlier distinctions. [16-17] Sponsler further asserts that "the fact that Lydgate's poem does not educate the reader into elite patterns of food consumption, does not teach conspicuous consumption and largesse, suggests a new valuation of food as symbolic good" (17). This, she notes, distinguishes the poem from social codes like the sumptuary laws, which seek only to reserve certain symbolic behaviors to the elite. It distinguishes the poem even more clearly from "The sotoltes at the Coronation Banquet of Henry VI," which certainly does encode 
elite patterns of food consumption and conspicuous culinary largesse. The distinction between these two modes of Lydgatean food-writing manifests itself in the types of manuscripts that preserve them. Sponsler notes that some manuscripts that include the "Dietary" are commonplace books commissioned by particular wealthy patrons, but many others are anthologies created not for a specific buyer but for any potential buyer in the marketplace of books; this would make the poem very much a part of the commodity culture of an expanding and increasingly literate commercial class. ${ }^{1}$ By contrast, two of the manuscripts containing Lydgate's "Coronation Banquet" are famously sumptuous collections dealing with chivalry, governance, and royal pomp, both intended for specific, very wealthy patrons; the other nine manuscripts are all chronicles, the semi-official and ostensibly authoritative records of history and public life. ${ }^{\text {i }}$ These would seem to represent a competing model of literary consumption to the one Sponsler infers from the "Dietary," one which seeks to habituate the minds and bodies of individual subjects to the ideology of the ruling elite. It may be an older and more conservative model-hierarchical, top-down, orthodoxical, and feudalistic-- but, at least in the early fifteenth century, it is still viable and retains some authority. 
Huizinga observed that the artifacts of fifteenthcentury court spectacle depended for their effect on the intense intermixture of performative and textual qualities, as in the great "Moses Fountain" of Claus Sluter:

Below the central part, and surrounding the base that is held up around the edge by angels, stand the six figures from the Old Testament who prophesied the death of the Messiah..., each with an attached banderole on which the prophesied text can be read. The entire depiction has to the highest degree the character of performance. This is not so much because of the fact that the tableaux vivants or 'personnages,' which during processions and banquets usually had figures with such banderoles attached to them, or that the Messiah prophecies from the Old Testament were the most important subjects of such representations, as because of the fact that this depiction has an unusually strong verbal effect about it. The words of the inscriptions have an emphasized place of importance. We only reach a full understanding of the work if we completely absorb the sacred import of those texts. (309)

Only now are historians of performance are coming to appreciate the textual nature of medieval spectacles, and it is clear that Henry VI's coronation banquet was in many ways 
deeply textual. At the same time, literary historians may need to develop a performative model of textuality. Lydgate's "Sotoltes at the Coronation Banquet of Henry VI," like many poems of the Lancastrian period, embodies a kind of spectacular textuality. It is an "occasional" poem in the sense that it means to preserve and to propagate in the realm of the text the spectacular, political, and verbal conditions of the original occasion. Such texts do not just script performances or commemorate performances; they recreate performances, re-staging the conditions of performance on the page. 
Portions of this paper were presented to the Columbia Medieval Guild Conference and the Fairfield Faculty Research Symposium, and at the University of Connecticut; the manuscript research was supported by a Fairfield University Faculty Research stipend. I would like to thank C. David Benson, Vincent Rosivach, Derek Pearsall, Frank Grady, Rebecca Krug, Robert J. Meyer-Lee, and Maura Nolan for their comments and suggestions.

i C.H. Herford and Percy and Evelyn Simpson, eds., Ben Jonson, Vol. 7 (Oxford: Clarendon, 1941), pp. 684-85. ii Johan Huizinga, The Autumn of the Middle Ages, translated by Rodney J. Payton and Ulrich Mammitzsch (Chicago: University of Chicago Press, 1996), p. 307. iii Richard T. Cooper and James Gerstenzang, "The Fox Visit: Chorizo Pozole, Pepita Bison, and No Extra Seats," Los Angeles Times, 6 September 2001, 19A.

iv Cooper and Gerstenzang. Such symbolism is standard for White House centerpieces. At President Clinton's state dinner for President Jerry Rawlings of Ghana in 1999 the candles and decorations were arranged "so that the centerpieces gave off hints of gold, red, and green-the colors of the Ghanaian flag" (Kalpana Srinivasan, "Clinton Toasts Ghanaian President," Chicago Sun-Times, 25 February 
1999, 24). When the Bushes hosted President Aleksander Kwasniewski of Poland on July 17, 2002, the table settings and the flowers were red and white, the colors of the Polish flag (Marian Burros, "Excrutiating Attention to Detail for State Dinner for Polish President," The New York Times, 18 July 2002) .

v Judy Keen, "Foes Taste Glam Side of White House," USA Today, 6 September 2001, 4A. For President Rawlings, Mesnier decorated the ice cream (flavored with mango and pineapple, native Ghanaian fruits) with a traditional kente sash (Srinivasan). For British Prime Minister Tony Blair the dessert depicted Big Ben, and for the Emperor of Japan it resembled bonsai trees (Burros).

vi Invitees to the Mexican dinner included athletes Anthony Munoz and Eduardo Najera and singer Gloria Estefan. Estafan, of course, is of Cuban extraction, but in this case being Latina was apparently sufficient, and in any event she was unable to attend.

vii Stephen Orgel, The Illusion of Power: Political Theater in the English Renaissance (Berkeley: University of California Press, 1975), p. 41. vii The indispensable encyclopedia of early English theatre remains Glynne Wickham's Early English Stages: 1300-1660, 3 vols. (London: Routledge and Kegan Paul, 1959, 1981). Still 
extremely useful as a survey of criticism on medieval drama is C. Clifford Flanigan, "Comparative Literature and the Study of Medieval Drama," Yearbook of Comparative and General Literature 35 (1986): 56-104.

ix Lawrence M. Bryant, "Configurations of the Community in Late Medieval Spectacles: Paris and London during the Dual Monarchy," in City and Spectacle in Medieval Europe, ed. by Barbara A. Hanawalt and Kathryn L. Reyerson (Minneapolis: University of Minnesota Press, 1994), pp. 3-33 (8). Among the many other studies in the field, see in particular Gordon Kipling, Enter the King: Theatre, Liturgy, and Ritual in the Medieval Civic Triumph (Oxford: Clarendon Press, 1998), and Sandra Logan, "Making History: The Rhetorical and Historical Occasion of Elizabeth Tudor's Coronation Entry," Journal of Medieval and Early Modern Studies 31 (2001): 25177. All modern analysis of English royal pageantry owes much to Sydney Anglo, Spectacle, Pageantry, and Early Tudor Policy (Oxford: Oxford University Press, 1969; second edition, Oxford: Clarendon, 1997). x See Wickham, Early English Stages, vol. 1, pp. 191-228; vol. 3, pp. 48-61. See also Robert Withington, English Pageantry: An Historical Outline, 2 vols. (Cambridge: Harvard University Press, 1918; reprinted New York: Arno Press, 1980), vol. 1, pp. 132-66, and, more recently, Kipling, Enter the King, and Lawrence M. Clopper, Drama, 
Play, and Game: English Festive Culture in the Medieval and Early Modern Period (Chicago: University of Chicago Press, 2001).

xi See R.A. Griffiths, "Propaganda and the Dual Monarchy," in The Reign of King Henry VI (Phoenix Mill: Sutton, 1998), pp. 217-228; J.W. McKenna, "Henry VI of England and the Dual Monarchy: Aspects of Royal Political Propaganda, 1422-1432," Journal of the Warburg and Courtauld Institutes 28 (1965): $145-62$.

xii See Derek Pearsall, John Lydgate (London: Routledge and Kegan Paul, 1970), pp. 160-91, and John Lydgate (1371-1449): A Bio-bibliography (Victoria: English Literary Studies, University of Victoria, 1997) pp. 28-32. See also V.J. Scattergood, Politics and Poetry in the Fifteenth Century (London: Blandford Press, 1971), pp. 71-76. xiii Griffiths, p. 220 .

xiv The text survives in nine manuscripts. While all include the menu of the feast and refer to the "soteltes," there is some variation in the detail and the order of the dishes served, notably in Mss. Lansdowne 285 and Pierpont Morgan 775. Other manuscripts (e.g., Cotton Vitellius A.xvi and Egerton 1995) give close paraphrases in prose of Lydgate's verses. The most complete texts are in Cotton Julius B.i (ff. 79r-80r) and London Guildhall Library 3133 (f. 129v). 
(I have personally inspected all except the Guildhall ms. and St. John's College, Oxford, Ms. 57.) For the Guildhall ms., known as "the Great Chronicle of London," see the edition of A.H. Thomas and I.D. Thornley (London: George W. Jones, 1938), pp. 152-54. Cotton Julius B.i is the basis for H.N. MacCracken, The Minor Poems of John Lydgate: Part II, Secular Poems, EETS O.S. 192 (London: Oxford University Press, 1934), pp. 623-24, with collation of Lydgate's verses from Lansdowne 285. The text is here quoted from MacCracken's edition. For descriptions of the manuscripts, see G.A. Lester, Sir John Paston's 'Grete Boke': A Descriptive Catalogue, with an Introduction, of British Library Ms. Lansdowne 285 (Cambridge: D.S. Brewer, 1985); Charles Letheridge Kingsford, ed., Chronicles of London (Oxford: Clarendon, 1905); A.E. Hartung, et al., A Manual of the Writings in Middle English, 1050-1500 ( New Haven: Connecticut Academy of Arts and Sciences, 1967), vol. 6, pp. $2116-17$

xv See, for instance, Eating Culture, ed. Ron Scapp and Brian Seitz (Albany: State University of New York Press, 1998). The symbolic significance of food has always been of central interest to anthropologists, and under their influence Huizinga observed the connection between feast and play: "Both proclaim a standstill to ordinary life. In both, mirth and joy dominate, though not necessarily-- for 
the feast too can be serious; both are limited as to time and place; both combine strict rules with genuine freedom. In short, feast and play have their main characteristics in common" (Homo Ludens: A Study of the Play-Element in Culture [Boston: Beacon Press, 1955], pp. 21-22). xvi "Furmenty" or "frumenty" was "unground, hulled wheat boiled in almond milk," usually seasoned and often colored with saffron (P.W. Hammond, Food and Feast in Medieval England [Stroud, Gloucestershire: Alan Sutton, 1993], p. 39). See also William Edward Mead, The English Medieval Feast (London: George Allen \& Unwin, 1931), p. 230. For medieval recipes see Thomas Austin, ed., Two FifteenthCentury Cookery-Books, EETS O.S. 91 (London: Oxford University Press, 1888; reprint 1964); "furmenty with venyson" is on p. 70, "vyande ryalle" on p. 32. xvii Granted, all of these dishes would not have been served individually to each diner but rather laid out together in the manner of a buffet. See Reay Tannahill, Food in History (New York: Stein and Day, 1973), pp. 221-2. It is also true that descriptions of exceedingly extravagant feasts are rare, and that only their frequent repetition by modern writers gives us an impression of the lavishness of latemedieval aristocratic life. See Christopher Dyer, Standards of Living in the Later Middle Ages: Social Change in England c.1200-1520 (Cambridge: Cambridge University Press, 1989), 
p. 90. Henry VI's coronation banquet, then, is all the more impressive for being exceptional.

xviii Hammond, Food and Feast, p. 137.

xix A leche was any firm or congealed dish - bread, jelly, pudding, etc. - cut into "leches," long, thin slices; see Austin, pp.134, 135; Constance B. Hieatt, "Making Sense of Medieval Culinary Records: Much Done, But Much More to Do," Food and Eating in Medieval Europe, Martha Carlin and Joel T. Rosenthal, eds. (London: Hambledon Press, 1998), pp. 10116 (110). The medieval custard was a quiche-like tart (Hammond 136); for "crustade ryal," see Austin 55. Fritters, sweet or savory, were ubiquitous treats; see Terence Scully, The Art of Cookery in the Middle Ages (Woodbridge: Boydell Press, 1995), p.136; Hammond 136. $x$ On the symbolism of the dual monarchy, including the evocation of St. Louis, see McKenna, pp. 151-57, and Lee Patterson, "Making Identities: Henry V and Lydgate," in Jeffrey N. Cox and Larry J. Reynonlds, eds., New Historical Literary Study: Essays on Reproducing Texts, Representing History (Princeton: Princeton University Press, 1993), pp. 69-107 (89-93) . xxi "Blaunde Surrey" (alias blandesore, blank de syry, etc.) entailed slices of meat pudding, dyed and set in spiced wine. Cf. Austin 121, 137; Constance B. Hieatt, et al., 
Pleyn Delit: Medieval Cookery for Modern Cooks, $2^{\text {nd }}$ ed.

(Toronto: University of Toronto Press, 1996), \#29. Borage was one of the more common herbs; cf. Hammond 43. xii On St. Denis and hagiography in medieval French politics see Colette Beaune, The Birth of an Ideology: Myths and Symbols of Nation in Late-Medieval France, trans. Susan Ross Huston (Berkeley: University of California Press, 1991), pp. $20-69$. xxiii See McKenna 158 . xxiv The "endored" roasts were gilded with a glaze of egg yolks. See Austin 128; Hieatt \#94. "Flampayne," or flampoyntes, was a tart decorated with pastry "points." See Austin 129; Hammond 136.

xxv The genesis of this alliance is narrated vividly by Peter McNiven in Heresy and Politics in the Reign of Henry IV: The Burning of John Badby (Woodbridge, Suffolk: Boydell Press, 1987) and its consequences are analyzed at length by Paul Strohm in England's Empty Throne: Usurpation and the Language of Legitimation, 1399-1422 (New Haven: Yale University Press, 1998). xxvi Anne Hudson, The Premature Reformation: Wycliffite Texts and Lollard History (Oxford: Clarendon, 1988). xxvii The Minor Poems of John Lydgate, Part I: Religious Poems, ed. by Henry Noble MacCracken, EETS E.S. 107 (London: 
Oxford University Press, 1911; reprint 1962), pp. 212-16. See Pearsall, John Lydgate, p. 170. xxviii "Henry VI's Triumphal Entry into London," Minor Poems: Part II, pp. 630-48. xxix As McKenna notes (161), the Duke of Bedford had this genealogy displayed in French churches. Bedford also commissioned a French versification of the genealogy by Laurence Calot, and Lydgate, at the request of Warwick, translated it as "The Title and Pedigree of Henry VI." See Pearsall, John Lydgate, p. 166. xxx See McKenna 161 and Richard Osberg, "The Jesse Tree in the 1432 London Entry of Henry VI: Messianic Kingship and the Rule of Justice," Journal of Medieval and Renaissance Studies $16(1986): 213-32$. xxxi Such an equation of the king with Christ might seem too blasphemous to be intentional, but McKenna (149) remarks a similar gesture in the medium of numismatics. In a French salute coined in 1423 for the infant Henry VI, the figures in the annunciation image common to such coins are, against all iconographic convention, reversed, putting the angel Gabriel on the viewer's right and the Virgin on the left. The switch places the angel behind the arms of England and the Virgin behind those of France. Given that the realms were ostensibly united by an English king and a French 
princess, McKenna argues that the coin iconically

politicizes the annunciation, with Henry VI in the role of the infant Jesus.

xxxii See Derek Pearsall, "Hoccleve's Regement of Princes: The Poetics of Royal Self-Representation," Speculum 69 (1994): 386-410 (particularly 403-8). See also James H. MacGregor, "The Iconography of Chaucer in Hoccleve's De Regimine Principium and in the Troilus Frontispiece," Chaucer Review 11 (1977), 333-50; W.R. Jones, "Lollards and Images: The Defense of Religious Art in Later Medieval England," Journal of the History of Ideas 34 (1973): 27-50. xxxiii This explanation of the politics of "aureate" diction would offer hypothetical response to the conundrum noted by Pearsall ("Hoccleve's Regement, p. 408): "How could the English language, with Chaucer, the prince, and Hoccleve as its promoters, serve the cause of orthodoxy and national identity when it was closely identified with Lollardy...? It may be that there is an important distinction to be made between Arundel, with his policy on the use of English for scriptural and theological purposes, and the prince, with his policy on the use of the vernacular in politics, administration, and poetry. This would not be an opposition of principle. Or it may be that the prince is making a preemptive strike, claiming English for the nation, embodied in himself, so that it will not become identified with 
Lollardy." Such a distinction seems established by the $1460 \mathrm{~s}$ and the composition of the morality play Mankind, in which the vice characters, associated throughout with Lollardy, speak a coarse, common, and comic English, while the virtuous and orthodox Mercy's latinate speech is the height of aureation. See also Nicholas Watson, "Censorship and Cultural Change in Late-Medieval England: Vernacular Theology, the Oxford Translation Debate, and Arundel's Constitutions of 1409," Speculum 70 (1995): 822-64. xxiv See Malcolm Lambert, Medieval Heresy: Popular Movements from the Gregorian Reform to the Reformation, 2nd ed. (Oxford: Blackwell, 1992), pp. 310-16 et passim. xxxv Stephen G. Nichols, "Seeing Food: An Anthropology of Ekphrasis, and Still Life in Classical and Medieval Examples," MLN 106 (1991): 818-851 (847). The trope of eating words was always available to the medieval imagination, deriving from biblical passages such as Christ's words in the Gospel of Matthew (4:4): "Not in bread alone doth man live, but in every word that proceedeth from the mouth of God." Langland makes conspicuous use of the trope in the banquet of Conscience in Passus 13 of Piers Plowman, where Will and Patience eat a "sour loof" (46) of penitential psalms while the hypocritical academic friar gorges on delicacies and drink. See John A. Alford, "Langland's Exegetical Drama: The Sources of the Banquet 
Scene in 'Piers Plowman," "Literature and Religion in the Later Middle Ages, ed. Richard G. Newhauser and John A. Alford (Binghamton: Center for Medieval and Early Renaissance Studies, State University of New York at Binghamton, 1995). Such a scene, however, is founded on the essential distinction between literal and figurative food. See James Simpson, Piers Plowman: An Introduction to the Btext (London: Longman, 1990), p. 144. The literal eating of words would seem to come for the Christian only in the Eucharist, with the consumption of the body and blood of Christ who is the Word. xxxvi On the intermingling of the sacred and the secular in other fifteenth-century banquets, see Susan F. Weiss, "Medieval and Renaissance Wedding Banquets and Other Feasts," Food and Eating in Medieval Europe, ed. Martha Carlin and Joel T. Rosenthal (London: Hambledon Press, 1998), pp. 159-174. Roy strong has recently remarked that in Renaissance and baroque banquets the monarch is increasingly elevated above and separated from his attendant lords, making the meal "resemble a secular version of the mass. The table is laid like an altar, bread and wine are consumed, the scene is the focus of ceremonial processing, ritual washing, the kissing of objects as though they were relics, genuflections as if before the sacrament. Even the ducal cup is elevated when carried in procession, a gesture 
that echoes the elevation of the consecrated chalice" (Feast: A History of Grand Eating [London: Jonathan Cape, 2002], p.127). xxxvii See Scully pp. 104-110; Strong, pp. 116-27; Hieatt, "Making Sense of Medieval Culinary Records," 110. xxxviii Strong, p. 120 . xxix Early English Stages, vol. 1, p. 212.

${ }^{x}$ See Huizinga's discussion, The Autumn of the Middle Ages, pp. 294-328.

xli Austin ( $\mathrm{p} . \mathrm{x})$ says that subtleties "were devices in sugar and paste, and apparently in jelly, and were, at any rate at times, made to be eaten." Wickham (Early English Stages, vol. 1, p. 211) cites the text of the banquet in defining "subtilty" as "a symbolic device in coloured sugar corresponding, in its attraction, to an elaborate wedding cake." McKenna calls them "decorated desserts" (157) and "pastry tableaux" (158). Hammond (142), on the other hand, says of the subtlety: "Sometimes it was an ornament wholly made of sugar or 'marchpane' (marzipan) that was eaten. They were not, however, always restricted to edible materials - the cook probably used whatever was necessary to make his design." See also Lorna J. Sass, "Serve It Forth: Food and Feasting in Late Medieval England," in The 
Anthropologists' Cookbook (New York: Kegan Paul

International, 1997), pp. 14-18.

xlii On the eating of nobles in effigy, see Allen S. Weiss, "Edible Architecture, Cannibal Architecture," Eating Culture, ed. Scapp and Seitz, pp. 161-68. Weiss describes a feast hosted by Casanova, which ended with a cake covered with the images of European nobility: "Casanova's passion for royalty was symbolically manifested in this attempt at complete devoration" (165).

xliii See Austin, pp. 57-64.

xliv Thomas \& Thornley, p. 117. See also Forme of Cury (printed in Curye on Inglysch: English Culinary Manuscripts of the Fourteenth Century, ed. by Constance B. Hieatt and Sharon Butler [London: Oxford University Press, 1985]) for the ingenuity of Richard II's chefs in constructing subtleties. Monstrelet's Chroniques records the subtleties at Henry VI's French coronation banquet; see McKenna, p. 158.

xlv Julia Boffey and A. S. G. Edwards, "Middle English Verse in Chronicles," New Perspectives on Middle English Texts, ed. by Susan Powell and Jeremy J. Smith (Cambridge: D. S. Brewer, 2000), pp. 119-28 (126). xlvi Ibid., p. 127. 
xlvii Ibid., p. 126. In this manuscript, Lydgate's verses are "written as prose, but underlined in red to signify its formal distinctiveness."

xlvii Several of the manuscripts containing the "Coronation Banquet" date from the first half of the fifteenth century, very close to the time of the banquet itself. St. John's College, Oxford, Ms. 57 was "compiled soon after 1430" (Lester, Sir John Paston's 'Grete Boke', p. 27). See also Ralph Flenley, Six Town Chronicles of England (Oxford: Clarendon, 1911). xlix "Eating Lessons: Lydgate's 'Dietary' and Consumer Conduct," in Kathleen Ashley and Robert L. A. Clark, eds., Medieval Conduct (Minneapolis: University of Minnesota Press, 2001), pp. 1-22.

1 Sponsler, p. 11. She cites Pearsall's (John Lydgate, p. 76) classification of such uncommissioned books as "speculative anthologies."

li The two non-chronicle manuscripts are British Library Ms. Lansdowne 285, the "Grete Boke" of Sir John Paston, and Pierpont Morgan Ms. 775, celebrated for its exceptionally beautiful and detailed illustrations of jousting and tournaments. They are related and share much material. See above, note 14 . 